\title{
Paul Flechsig's System of Myelogenetic Cortical Localization In the Light of Recent Research in Neuroanatomy and Neurophysiology Part II
}

\author{
ALFRED MEYER
}

\section{NEUROANATOMICAL AND NEUROPHYSIOLOGICAL ADVANCES IN THE LAST THREE DECADES}

\section{The "sensory centres"}

In 1896 Flechsig was still under the influence of Hermann Munk (1890) who had assumed that the cortex consisted of sensory centers, each equipped with efferent descending projection systems - olfactory, visual, auditory and - anterior to the last, the somatic sensory sphere ("Körperfühlsphäre"). This sphere also contained the kinaesthetic images of motor action induced by efferent fibers in the subcortical ganglia which, from Burdach (1819-26) until the time of Meynert, had been widely regarded as the highest motor centers. In 1905a, however, Flechsig had shed most of the influence of Munk. By then he had taken cognizance of the research of Grünbaum and Sherrington (1902, 1903) and realized that "in the highest anthropoid all stimulable points of the type of Fritsch and Hitzig are concentrated within one gyrus, namely the precentral gyrus, so that we can call this the motor gyrus . . . in man, too, the motor centers of the type of Fritsch and Hitzig are restricted to the precentral gyrus and the immediately adjacent part of the first frontal convolution. The central sulcus here too is the posterior boundary of the motor zone ... Occasionally a larger or smaller part of the motor centers, especially of the fingers, gets into the postcentral convolution, but, according to my own embryological studies, only exceptionally. As a rule we have to assume that all voluntary motor impulses leave the cortex from the precentral gyrus ...."

"Embryology shows very clearly pathways entering the motor gyrus from below which are in connection with peripheral nerves subserving the general sensitivity of the body. Only a few of these pathways end immediately between the motor cells ... Much more numerous are the sensory pathways which enter the postcentral convolution, that part of the cortex which anatomically as well as functionally is most intimately connected with the motor zone, and embryologically is nearest to it. Pathological observation shows therefore, that isolated lesions of the postcentral convolution are much more regularly followed by disorders of sensibility, yet these observations do not preclude that all sensory qualities are connected with both central convolutions, only quantitatively in a very different manner" (von Bonin, 1960, pp. 183 and 184). With the assumption of a separate influx of thalamic fibers into both Rolandic gyri Flechsig, as we shall see presently, anticipated, at an early date, the probable solution of a vexing problem that later investigators had to face.

Flechsig (1905a) was early in accepting Grünbaum and Sherrington's "motor cortex" within the precentral cortex and adjacent part of the first frontal convolutions in the human brain - with minimal overspill into the ventral part of the postcentral gyrus; he was closely followed by Mills and Frazier (1905-1906), Cushing (1908) and Krause (1911). Moreover, from his own embryological research Flechsig concluded that the postcentral cortex was predominantly sensory. This was four years before Cushing (1909) reported the responses to his famous electrical stimulations in the postcentral gyrus of two conscious patients: they both felt sensations of tingling and numbness in bodily parts which closely corresponded with analogous motor phenomena in the precentral convolution. 
Recent work on the temporo-parietooccipital region

Much of the criticism of Flechsig was based on his contention that this region is the seat of intelligence (The "logos" in its double semantic significance as word and conceptual thought). A beginning of a better formulation was made in 1948 when Ritchie Russell spoke of the "tools" of intelligent behavior, thus taking the sting out of the criticism. In 1961 McFie hailed the advent of a "New Phrenology" and Piercy (1964) concluded "that general intelligence is not mediated indifferently by the brain as a whole, and that specific aspects of intelligence may be selectively affected by focal lesions" an interpretation which is close to Russell's "tools".

\section{ANATOMICAL ASPECTS}

In 1969, Jones and Powell began their comprehensive work on the finer organization of the zone by investigating the connexions of the somatosensory cortex in the rhesus monkey by making large ablations in motor and sensory and also in other cortical regions. After short survival the animals were killed and the brains investigated by the Nauta-Gygax or Fink-Heimer methods. The authors found that S1 and S2 are reciprocally connected with one another and with area 4 in a topographically organized manner. Each also sends fibers to the supplementary motor cortex in area 6 , but only SI projects to the parietal cortex, area 5. Apart from area 4 no other cortical area sends fibers to the somatosensory cortex. As the authors reported in a subsequent paper (1970a) this is the only major point of disagreement with the findings of Pandya and Kuypers (1969) who, applying a similar technique in monkey's brains, had described a projection from area 6 to the postcentral region.

Jones and Powell (1969) also found that areas 3, 1 and 2 (which constitute S1) are interconnected reciprocally by fibers which do not exceed the borders of S1. Part of area 3 (3a of C. and O. Vogt, 1919 and M. Vogt, 1928) is a transitional zone between area 4 and the somatosensory cortex, but according to Powell and Mountcastle (1959) from the standpoint of function, it must still be considered to belong to the sensory cortex. Jones and Powell postulated that area $3 a$ may receive afferents from the skeletal muscles and such a pathway was indeed proved to exist by Phillips, Powell and Wiesendanger (1971): by recording cortical potentials after peripheral stimulation, these authors described a direct pathway from slow-threshold muscle afferents of hand and forearm to area 3a of the baboon's cortex. That there is indeed no direct connexion between the two was confirmed in an ingenious experiment by Wiesendanger (1973): stimulating the afferents from the hand and forearm muscles and comparing the potentials in the relevant areas in the sensory and motor cortices, he showed that the shortest precentral latencies were more than twice as long as those measured in the postcentral; he was led to postulate additional and perhaps complex corticocortical connexions between $3 a$ and 4 .

The anatomical connexions between the parietal, temporal and occipital cortex have aroused great interest during the last three decades (Kuypers, Szwarcbart, Mishkin and Rosvold, 1965; Pandya and Kuypers, 1969; Jones and Powell, 1970a; Nauta, 1971, to mention the most important publications). There is much agreement between the individual contributions, as Jones and Powell pointed out in their paper on the converging sensory systems. According to these authors, the principle of convergence is simple: each primary sensory area projects to the adjacent field within the parietal and premotor area 6 . For example, the somatosensory cortex projects to Brodmann's area 5 and the supplementary motor cortex in area 6 which, in their turn, are reciprocally interconnected. Area 5 sends fibers into the adjacent area 7 and the rest of area 6 . The primary auditory cortex has reciprocal connexions with area 22 (superior temporal cortex) and from there to areas 21 and 20 . The striate cortex sends connexions to the preoptic belt and from there to area 7 ; this appears to be an important intermediary station where several sensory systems are collected, sending fibers to the areas 20 and 21 in the inferior temporal cortex which forms the end station within Flechsig's posterior associational center. Jones and Powell (1970a) suggested that the temporal end station was situated in the depth of the superior temporal sulcus which may be the homologue of areas 39 and $40-$ the human supramarginal and angular gyri.

\section{FUNCTIONAL ASPECTS}

During the last decades, great interest has been manifested in the investigation of function in the parietotemporo-occipital region - Flechsig's posterior terminal center. Most probably it was stimulated by the classic monograph of Critchley who, in 1953, reviewed the literature of previous relevant work (including his own). Even earlier, Kluver and Bucy (1939) had shown that bilateral temporal lobectomy in monkeys resulted (among other defects) in non-recognition of visual objects which are still recognized by tactile criteria (the authors' "psychic blindness"). The ventral temporal cortex which is responsible for this symptom has been further investigated by Mishkin and Pribram (1954), Mishkin (1954), Ettlinger (1959), all demonstrating that ablation of this region resulted in a defect of visual pattern discrimination. Eccles (1977, pp. $264 \mathrm{ff}$ ), who had described the earlier stages of the reconstruction of the retinal image within the visual cortex, in parallel with the gradual preponderance of complex and hypercomplex cells over simple cells (Hubel and Wiesel, 1965, 1968) from areas 17 to 19 , regarded the inferior temporal cortex as an even higher station of retinal reconstruction. He quoted Gross et al. (1974) and Weiskrantz (1974) who found that the neurons here have more exacting stimulus requirements than the lines and angles adequate for complex and hypercomplex neurons. Weiskrantz demonstrated how monkeys can build up a three-dimensional model of an object in visual imagination and thinking.

Interdependence between the inferotemporal cortex and the "circumstriatal belt" of Kuypers et al. was observed by Ettlinger, Iwai, Mishkin and Rosvold (1968, monkeys): inferotemporal lesions impaired visual discrimination, but did not abolish it; only in combination with a lesion in the 
circumstriate belt complete deficits resulted and in some cases relearning was prevented. In this same region Denny-Brown and Chambers (1958) noted that the parastriate and peristriate cortex, even in the absence of area 17, can activate accurate placing, shape, discrimination, reaching and avoiding. Their findings were confirmed by Ettlinger and Kalsbeck (1962) in monkeys.

\section{CELLULAR PERPENDICULAR COLUMNS}

Mountcastle (1957) described columns perpendicularly penetrating the whole of the cat's somatosensory cortex which he investigated by recording cortical responses to appropriate peripheral stimuli. The columns had a cross-sectional width of the order of $0.5 \mathrm{~mm}$. He distinguished three categories according to the nature of the peripheral stimuli: they were, in rostro-caudal order, cell responses to mechanical excitation of hairs, pressure of skin and mechanical 'deformation' of deep tissues (joints, joint capsules, but not muscles). He concluded that his results warranted the hypothesis that there existed in the somatosensory cortex, an elementary pattern of organization, vertically oriented and capable of input-output function of considerable complexity which was independent of horizontal intracortical spread of activity.

As Mountcastle admitted, he was not the first to describe a vertical organization of a sensory system: Marshall and Talbot (.1942, p. 119) had found in the visual cortex of cats that, following stimulation of the lateral geniculate body, the first spike was recorded from the fourth layer; a second small spike followed "as a notch" nearby which they tentatively interpreted as activity in an internuncial neuron. A third spike probably indicated (as they pointed out) activity of neurons ascending from layer 4 into layers 3 and 2 .

Hubel and Wiesel's distinction of simple, complex and hypercomplex nerve cells in the visual cortex and their significance for the successive cortical reconstruction of the retinal image, has been mentioned earlier in the present paper. Influenced by Mountcastle's discovery of vertical cellular columns in the somatosensory cortex of the monkey, these workers found similar columns in the visual cortex. In 1963, they described, in cats, columns reaching from the surface of the cortex down to the white matter. Their cells corresponded to a specific shape of retinal light stimuli and their orientation within the retinal field. To these 'orientation columns' they added (1969, in monkeys) a second type of column, the nerve cells of which reacted to ocular dominance. Hubel and Wiesel believed that ultimately further columns may be discovered, but - in the last of their series of papers which I have reviewed Levay, Hubel and Wiesel (1975) had not added any new columns.

Like Mountcastle, Hubel and Wiesel believed - so far - the column to be a physiological concept, but were convinced that an anatomical substrate would be found. The radial entrance of specific thalamocortical afferents (which Ramón y Cajal had described in 1899 and 1904) served as a model for the view of Lorente de No (1949) and von Bonin $(1942,1944)$ that besides the laminar architectonic stratification there existed a no less important perpendicular cortical stratification. One of the earlier perpendicular systems was also described by Flechsig (1905a), since his chief criterion for ontogenetic timing was the incoming radial fiber. Hubel and Wiesel acknowledged that the nerve cells of their columns were grouped around or in between the incoming fibers; it may well be that in some way they may have synaptic contacts with the neighboring nerve cells which they may influence. Using a Nissl counterstained Golgi method, von Bonin and Mehler (1971) described and illustrated the grouping of nerve cells around vertical fibers; this close relationship was most distinct in the visual cortex of primates (see their fig. 2).

Hubel and Wiesel (and their associates) made several attempts to demonstrate columns anatomically. In their 1969 paper, they used the Fink and Heimer modification of the Nauta-Gygax method, since conventional Nissl or Golgi staining gave no hint of any eye-dominance groupings. After making very small lesions (as small as a few hundred microns) in single layers of the lateral geniculate body, they were able to observe degeneration within the striate cortex, mainly in a vertical sheet of the fourth layer which they interpreted as corresponding to the eye preference column. From this position, neurons above and below this layer can be secondarily influenced.

In 1972. the same authors repeated the experiment in 18 macaques. They first made lesions in one of the two most dorsal parvocellular layers of the lateral geniculate body. Before the lesions were made, the position of geniculate receptive fields was noted on the projection screen. In due course, Hubel and Wiesel were able to observe terminal degeneration within the visual cortex. They found discrete bands of degeneration in layer IV. $0.5-1.0 \mathrm{~mm}$ in width, separated by bands of similar interbands which were normal. In serial sections these appeared more or less as a series of regular, parallel, alternating degenerating-rich and degenerating-poor stripes (see their figs. 1 and 10. The bands were mainly placed in layer IVc with a second minor input to a narrow strip in IVa. Very few degenerating fibers ascended to layer $\mathrm{I}$.

The third attempt at demonstrating a morphological substrate was made in 1974 (Wiesel, Hubel and Lam). By an autoradiographic method of transsynaptic transport they injected a solution of mainly L-fucose and $L$-proline into the vitreous space of the monkey's left eye. Investigating the Nissstained lateral geniculate body, they found the corresponding layers 2,3 and 6 to be "strongly labelled". In the striate cortex, dark field illumination revealed bright, more or less vertical bands of silver granule accumulations confined to layer IVc and more faintly - to IVa.

In 1975 Levay, Hubel and Wiesel observed (again in macaques) alternating pale and darker stained bands on staining with Liesegang's reduced silver method. These are clearly seen in their fig. I. where both Nissl stained and Liesegang reduced stripes were shown side by side in perpendicular sections; the light bands in the fourth layer were $50 \mu$ wide in contrast with the $300 \mu$ wide dark bands. In order to explain this observation, the authors determined (in another macaque) the width of the eye-dominance column, by sending the exploring electrode along the limits of this column. They then marked these limits by making a number of electrolytic lesions. Finally, they sacrificed the animal and fixed the brain. On section they found all their lesions, a total of 12. corresponded to places within the pale bands which they had seen in the first macaque. They concluded that the dark bands corresponded to single eye preference columns, whereas the pale bands were indicative of the boundaries between columns. 
No device has yet been found to demonstrate the other type, their orientation columns.

In investigations into the morphological substrate of columns, Golgi methods have been much used. Sholl had the historical merit of having brought about, by his monograph of 1956, a veritable renaissance of Golgi investigation (Colonnier, 1966; Globus and Scheibel, 1967; The Scheibels, 1970; Marin-Padilla, 1970; Tömböl, 1972; Lund, 1973; Jones and Wise, 1977; and many more to whom reference will be made in due course). Sholl's fig. 3 (1955) and 11 (1956) could serve as an illustration of an inputoutput cortical column, though of greater width, even before Mountcastle had described his "column". Among the other contributions with the Golgi method, Colonnier's "structural design of the neocortex" provided a good review of the problem at the time of its publication. We learn from him how much (as early as 1899) Ramón y Cajal had already known of the structural cortical design: He was certain that most specific afferents ended in layer IV. He also investigated the rôle of Golgi 2 type of nerve cells. In the human brain, Cajal described one particularly numerous type which, in 1911, he named "fusiform cell with a double dendritic bouquet", because of its forking processes from both poles of the cell. Although these cells themselves are found in layers 111 and IV, their radial arborizations are so long that they may extend throughout the thickness of the whole cortex, and they may be so numerous that adjoining axonal arborizations may touch each other, forming together a long vertical fringe and making contact with many pyramidal cells. Colonnier proposed the interesting hypothesis that the cells with a double bouquet may have an inhibitory function, and this may form the walls of the columns. He mentioned an experiment by Szentágothai (see Szentágothai 1965a \& b), who, in order to ascertain the tangential spread of fibers, made cuts perpendicular to the pial surface. He found (with the Nauta technique) that terminal degeneration extended in both directions for several $\mathrm{mm}$ in layer I, but not more than a few hundred $\mu$ in deeper layers.
Later, (in 1975, p. 70) Szentágothai and Arbib agreed with Colonnier that inhibition by Golgi type 2 cells seemed to determine the lateral limits of the columns.

Golgi investigations were supplemented by contributions with other methods: degeneration methods were employed by Szentagothai (1965a \& b), while Whittacker and Gray (1962), Molliver and van der Loos (1969), Jones (1968) and Jones and Powell (1970b) preferred the electron microscope. Quite a few workers used more than one of these methods: Szentagothai always employed all three according to suitability.

So far, the most convincing evidence for the reality of a vertical column has become available through the discovery by (T.A.) Woolsey and van der Loos (1970) and van der Loos and Woolsey (1973) in the mouse. Using a combined Nissl-Cox-Golgi method they observed, in layer 4 of $\mathrm{S1}$, multicellular cortical units which because of their form they named "barrels" - roughly cylindrical, $100-400 \mu \mathrm{m}$ in diameter. Each barrel was composed of a ring of cells surrounding a hollow inside. The barrels were separated by an acellular septum. In the posteromedial field of layer 4, the barrels were of greater size, of elliptical shape and organized into 5 distinct cellular rows which corresponded to the 5 rows of whiskers, one of the peripheral sense organs of the mouse, and of some other rodents. In 1973 , the authors were able to show that if at birth one of the rows of vibrissae was destroyed, the relevant cellular row of the corresponding barrel remained undeveloped (as reproduced in fig. 18 of Szentagothai and Arbib, 1975, from van der Loos and Woolsey's publication of 1973). The authors were confident that their barrels corresponded to the columns of Mountcastle.

Meanwhile Mountcastle and his associates had turned their attention to the more posterior parts of the parietal lobe, especially areas 5 and 7 , where they also described the same vertical organization as in the somatosensory cortex. Furthermore, Mountcastle, with Lynch, Georgopoulos, Sacata and Acuna (1975) and also Mountcastle alone (1975) made interesting observations on the function of areas 5 and 7 in relation to motion: exploring 17 hemispheres of 11 monkeys, they found that the majority of nerve cells in area 5 were activated by passive rotation of the limbs at their joints movements necessary for manual exploration of extrapersonal space. On the other hand, the majority of neurons in area 7 have a similar "command function" of movements under visual guidance. Mountcastle and his colleagues proposed that several of the abnormalities that occur in humans and in monkeys can be understood as deficits of the will to explore with hand and eye the contralateral half-field of space.

Mountcastle has not been quite without predecessors. In 1936 (p. 446) Foerster had touched on the possibility that "the gyrus parietalis superior constitutes a self contained sensory-motor field which relates to the Totality of the body." Flechsig was more concrete. In 1905a he said: "I only remind you of the connection between motor impressions of the hand and optic impressions. To look for the memory residues of this whole complex of associated sensations in the central convolutions does not correspond to the facts. It is much more likely that this is situated in the parietal convolutions. In cases of lesions of the middle central zone where the faculty has been lost to recognize the normal bodily form of external objects, one can in the long run only show a disturbance of the joint sensations which evidently makes it impossible to feel in three dimensions or disturbs the usual connections of joint sensitivity with external impressions and the memory images of former touch and visual impressions." (quoted from Bonin, 1960, p. 185).

However astonishing and prescient Flechsig's observations may have been, it remains the great merit of Mountcastle and his associates to have provided the indisputable experimental proof.

In addition to his qualities as a scientist, Mountcastle is a philosopher of science. He began his Dean's lecture of 1975 by saying that it was a major achievement of the brain sciences in the last decades to make penetrating discoveries how our brains compose and update our central images of the world. And at the end of the lecture he made a relevant quotation from the philosopher-emperor Marcus Aurelius, written eighteen centuries ago. One detects the same philosophic spirit in his Sherrington Memorial lecture of 1978. He, however, differed from Sherrington who accepted a 
provisional dualism between brain and mind, whereas Mountcastle believes that "success in the laboratory arena is linked to the identity hypothesis in one or another of its various forms."

I must abstain from reviewing detail of the rich content of this lecture: only a few points can be discussed here. On p. 16 he emphasized the importance of using a combination of neurophysiological and neuropsychological methods for experimental research of brain function. This method, he continued, has, within the last decade produced a wealth of new facts concerning motor and sensory functions and may be helpful in studying the mechanisms of more complex behavior. Most remarkable are his "speculative propositions" on the relations between parietal lobe function and consciousness (p. 27). $\mathrm{He}$ regards the profound contralateral neglect of their defects by patients with parietal lobe lesions as a partial loss of consciousness. This conclusion has met with praise from Critchley (1978, p. 233) who also compared Mountcastle's combination of experimental research and philosophical outlook with that of Sherrington in whose memory Mountcastle's lecture was given.

Here is the place to mention the investigations of Libet (1966) into motor reactions to sensory stimuli at cortical level and their conscious experience. He demonstrated that there is a latency of $0.5-1 \mathrm{sec}$. between the moment of sensory-motor reaction and its conscious experience. It is known that only $0.015 \mathrm{sec}$. is required for transmission from the skin to the cerebral cortex, as shown by the evoked motor response. The further delay required to make them conscious may well take place within the parietal cortex. Later Libet (1973) made investigations on conscious human patients, using what Eccles (1977, pp. $256 \mathrm{ff}$ ) called very ingenious procedures to test his hypothesis.

Kornhuber (1974) described an interesting counterpart on the motor side between readiness to action and the motor action itself. A "readiness potential" and a "premotion" potential can be demonstrated before the onset of the movement; both were bilateral and widespread over prefrontal and parietal regions.

\section{NEURAL SUBSYSTEMS}

Before we leave the posterior association field, a few remarks are necessary on what variously goes under the names of neural subsystems, modules or integral patterns. The discussion of these systems has recently been intense: many contributions to "Neuroscience's Second Study Program" (Schmitt, 1970, Ed.) were dedicated to this problem. Many authorities (including Eccles, 1977, Phillips and Porter, 1977 and Young, 1978, 1979) have recognized their reality as physiological concepts. (Young's, 1964, "A model of the brain" may well have acted as an early stimulus in the search for neural submechanisms.) Eccles (1977, pp. 235 ff) attributed the introduction of the modular concept and the investigation of its structural basis mainly to Szentagothai. Eccles is certainly right about the great contributions Szentagothai has made to the problem, as the latter's informative paper of 1975 clearly demonstrates. However, in this paper and in his book with Arbib of the same year (on p. 59), he gives priority to Scheibel and Scheibel (1958) who, they say, made the first explicit statement on a modular arrangement in the reticular formation of the brain stem, describing it as a series of disc-shaped patterns stacked in perpendicular orientation to the brain stem axis. Szentagothai and Arbib (1975) called this "an elegant model". Since then the Scheibels have extended similar investigations to the spinal cord (1969) and to the thalamus and the somatosensory cortex (1970). The vertical column is generally regarded as the most important module so far. Eccles and the Scheibels often speak of them as "columns or modules'. They may be compared to integrated micro-circuits of electronics (see fig. 17 of Szentagothai and Arbib).

According to Eccles (1977, p. 241) no quantitative data about the number of cells in these basic units are yet available. The number may be surprisingly large, up to 10,000 cells, among them hundreds of pyramidal cells and many more of other neurons.

Columns are not confined to sensory regions but have been found in other regions including the motor cortex (Jones and Wise, 1977).
THE ANTERIOR ASSOCIATION CENTRE - ANATOMICAL ASPECTS

In his early publications around the turn of the century, Flechsig's investigations especially of the late myelinating fields, were not yet complete, as he himself admitted. From the description in his book of 1920, however, it seems that his anterior terminal zone is identical with the first and second convolutions of the prefrontal cortex (see his list of late myelinating fields 37 - 45 on p. 15). In 1896 Flechsig considered the anterior portions of the gyrus rectus to be part of the anterior association zone, but in 1898 he excluded the whole third frontal convolution from what from now onward he named the terminal zone. Even in 1920 (figs. 1 and 2, figs. 3 and 4 of the present paper) the third frontal convolution has numbers below the terminal fields though high within the scale of intermediary fields. This is interesting because the third frontal convolution together with the angular and supramarginal gyri have been accepted to be the most recent acquisitions, though they may not be exclusive to man (see my review 1971, pp. 150-151). Flechsig (1920) gave the triangular part of the third frontal convolution the number 35 in contrast to 45 for the second frontal gyrus. Likewise in the parietal lobe, the angular gyrus is awarded the number 42 against 37 for the gyrus supramarginalis. Does this mean that the angular gyrus has become more established (or "sessile") than the more recent supramarginal convolution? If so, this would also indicate that the area triangularis is even more recent than the supramarginal gyrus - a problem, perhaps, of interest to future "morphogenetic" research and, in particular, to comparative myelogenetic studies in subhuman anthropoids.

One of the problems which Flechsig admitted he could not solve was whether and how the anterior and posterior fields are interconnected. This problem has been amply investigated by several teams of workers (Pandya and Kuypers, 1969; Pandya, Hallett and Mukherjee, 1969; Jones and Powell, 1970 and Nauta, 1971). The interconnexions of the posterior association zone have already been discussed on pp. 96 of the present 


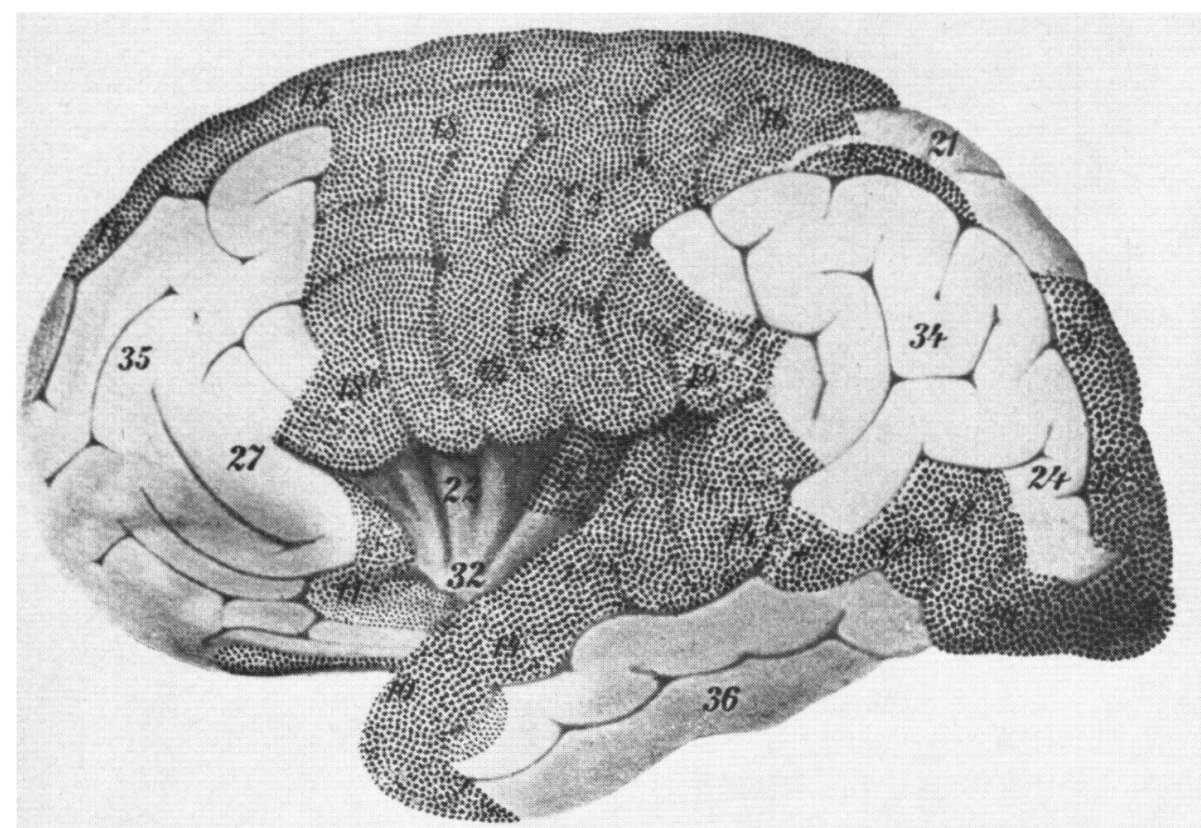

Fig. 3.

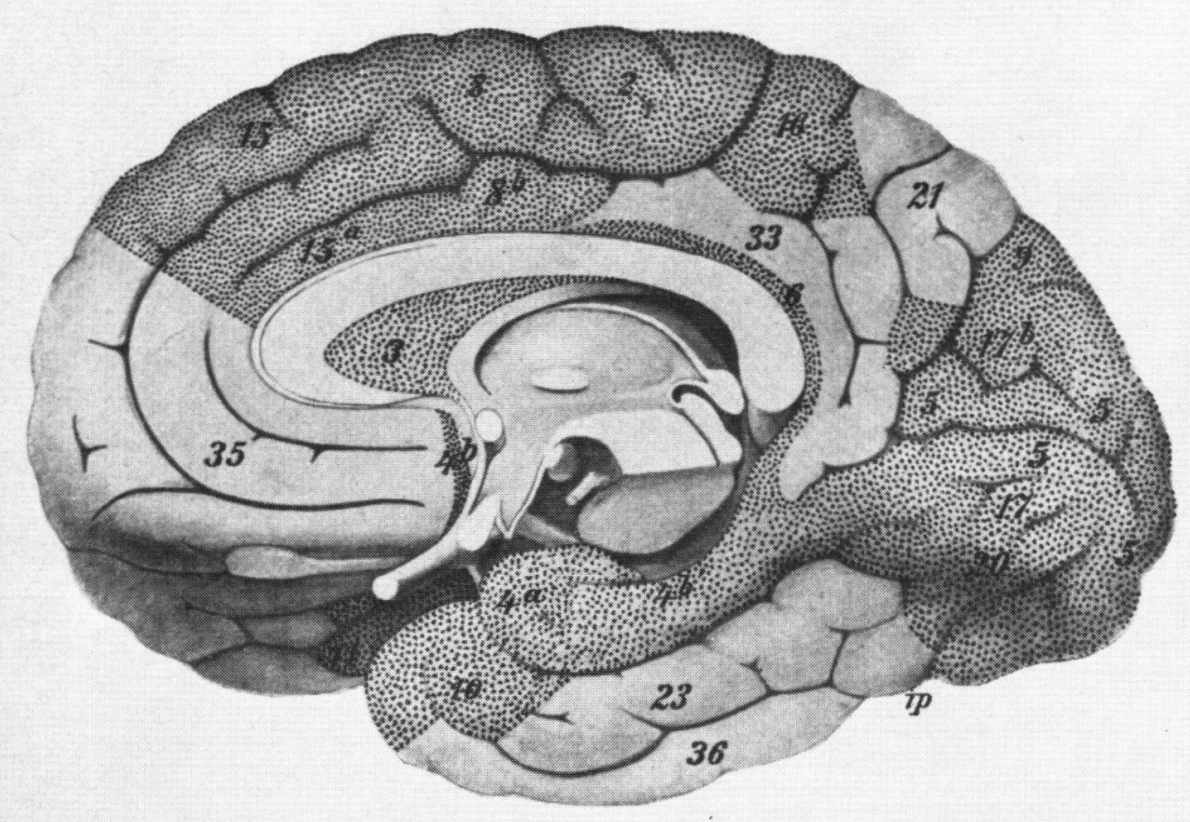

Fig. 4.

Figures $/$ and 2 - (reproduced from figs. 3 and 4 of Flechsig, 1905, by courtesy of the Librarian, Royal Society of Medicine, London): showing the myelogenetic fields numbered according to the time of myelination on both lateral and medial cortical surfaces. The lightly coloured fields correspond to Flechsig's terminal zone, as the high numbers indicate. Further explanation in text.

paper. The general principle seems to be that fibers from the somatosensory, visual and auditory cortex all converge to a point within the depth of the superior temporal cortex in monkeys. From the temporal cortex pathways to the prefrontal region may take their origin: a direct one via the uncinate bundle and an indirect one from areas 21 and 22 via the inferior thalamic peduncle to the magnocellular mediodorsal thalamic nucleus which in turn project to the prefrontal lobe (Nauta, 1971).

I cannot go into detail of Nauta's important paper, but his main conclusions are that the parietal and temporal regions have a reciprocal relationship with the prefrontal lobe, which thus receives and responds to impulses from visual, auditory and somatosensory cortices. The prefrontal lobe is also intimately connected reciprocally with the hypothalamus, the reticular ascending tract and other parts of the limbic system - a connexion which informs it about the organism's internal milieu and its importance for affective life and emotions. Interruption of the former connexion results in loss of foresight and programming-section of the latter to the well-known emotional change in patients with bilateral frontal lesions.

In their paper in which they first described expectancy waves Grey-Walter, Cooper, Aldridge, McCallum and Winter (1964) have supplied electroanatomic proof for the connexion between the anterior and posterior centers of Flechsig. For therapeutic purposes these authors have implanted in patients multiple electrodes in the prefrontal cortex: they noticed convergent responses to auditory, visual and tactile stimuli in most regions of medial, lateral and orbital frontal cortex.

\section{FUNCTIONAL ASPECTS}

It will be remembered from p. 6 that Bonin (1960) was much attracted by the modern ring in Flechsig's views on frontal lobe function and, in particular, that he thought that consciousness of the self ("Selbstbewusstsein") was the fundamental function of the frontal association area. I accepted von Bonin's opinion both in 1971 (p. 116) and in 1974 (p. 566). However, this interpretation needs correction. As early as 1895 Bianchi proposed that "The frontal lobes are the seat of coordination and fusion of the incoming and outgoing products of the several sensory and motor areas of the cortex ... the frontal lobes would thus sum up into series the products of the sensorimotor regions, as well as the emotive states which accompany all the perceptions . . . Thought, even when at work in the domain of pure conceptions, has in most men an inhibitory power . . ." Bianchi confirmed and amplified this view in 


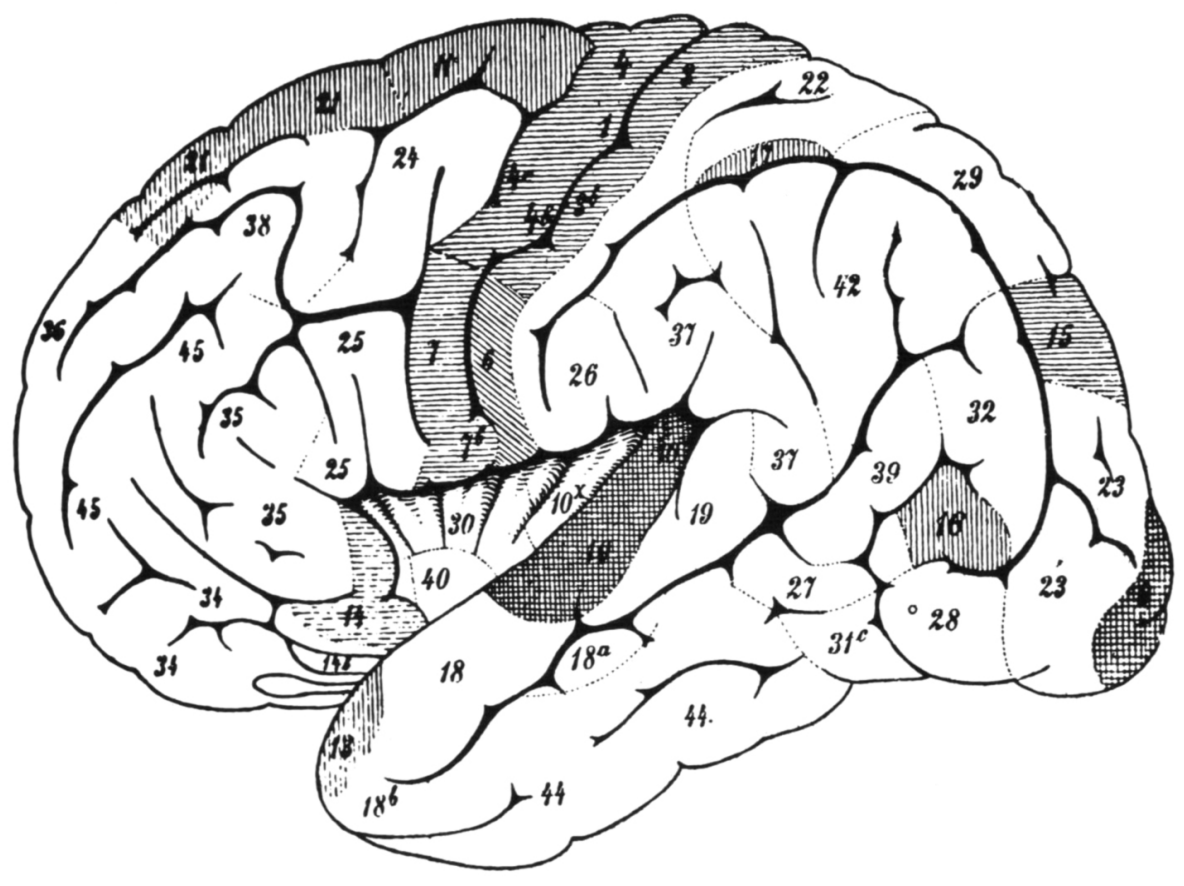

Figure 3 - (reproduced from fig. I of Flechsig, 1920, by courtesy of the Librarian, Rockefeller Medical Library, Institute of Neurology, London). Explanation in text.

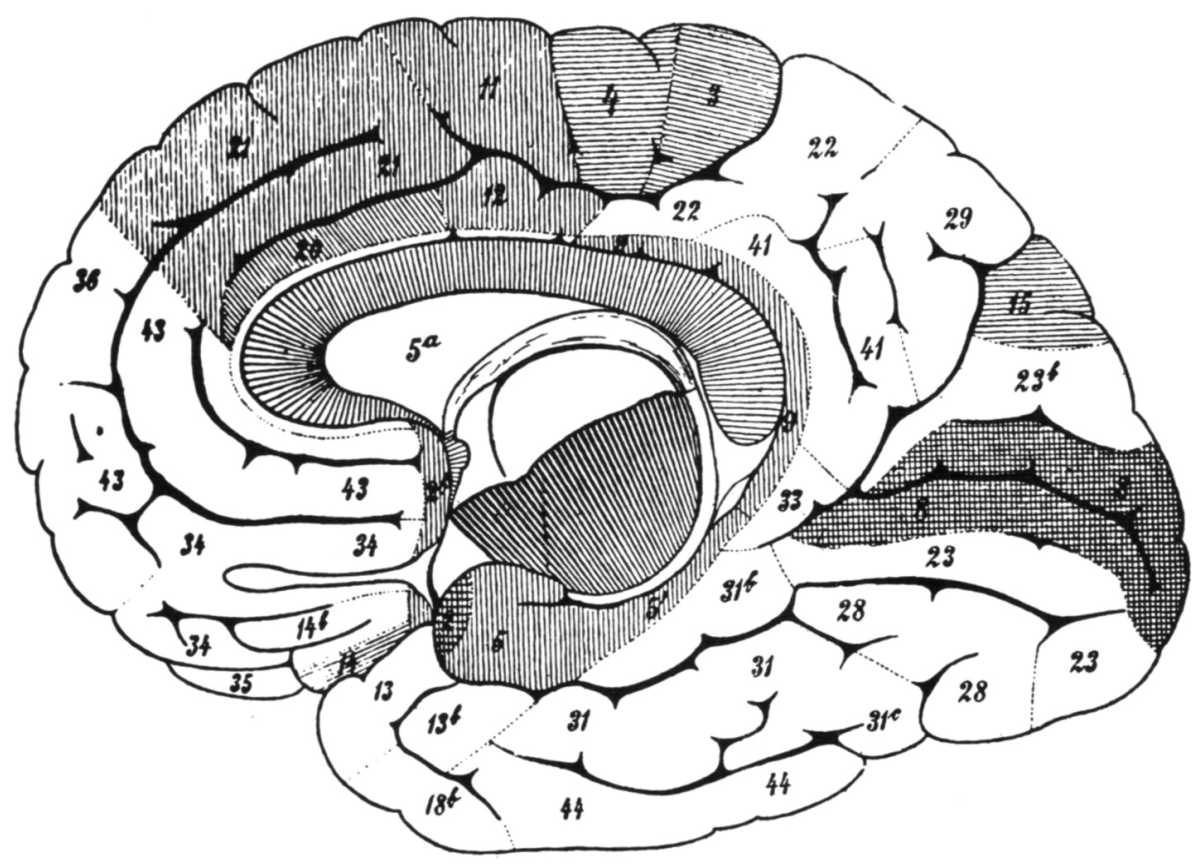

Figure 4 - (reproduced from fig. 2 of Flechsig, 1920, by courtesy of the Librarian, Rockefeller Medical Library, Institute of Neurology, London). Explanation in text. his monograph of 1922 and it definitely influenced Brickner's (1936) "synthesis", the "delaying action of the frontal lobe" of Cobb (1943) and has been further developed by DennyBrown (1951). This is also the gist of Nauta's conclusions in 1971: processing of sensory and motor impulses. foresight or, in the language of neuropsychologists, programming.

Mountcastle (1978, p. 26) discussed the relation of the parietal lobe to consciousness. He considered it likely that "the internal construct of the image of self and self in the world, and for the projection of attention into the external world, is an essential part of conscious awareness and conscious action." This is true not only in man; even the monkeys which he used in his own experimental work showed a withdrawn self-isolation and probably a reduction of consciousness after bilateral ablation of the parietal cortex. If any further proof was necessary, it has been provided by Sperry (1974): he showed in patients in whom the dissection of the hemispheres included the parietal lobes, consciousness of the self was preserved in the major hemisphere, while it was lost completely in the minor hemisphere. This did not happen when the hemispheric dissection was confined to the anterior and middle parts (Gordon, Bogen and Sperry, 1971): this suggests that frontal lobe function was not a major factor. Sperry believed that selfconsciousness was closely related to the receptive-semantic language centers in the dominant hemisphere. Penfield (1958), Sperry argued, had been wrong in placing his "centrencephalon" as the highest station for the control of consciousness into the higher brain stem. Deep-seated lesions only produce unconsciousness because they interfere with the ascending reticular formation necessary for cortical activity.

\section{CONCLUSIONS}

It has been the main purpose of this paper to show the unusually close relationship of Paul Flechsig's work on cortical localization with the results of neuroanatomical and neurophysiological research during the last three decades. A complete history of this recent history was, however, not 
intended: I have had to restrict myself to present the main trends of this research. Moreover, some of these results were not yet confirmed, while others were still at the stage of intriguing hypotheses, not yet accessible to a definitive historical verdict.

That some of the most exciting achievements have been made within the posterior "association zone" underlines the closeness of the recent research with Flechsig's work. I cannot here go into detail, but were he alive today, Flechsig would be gratified to find that many of the questions which he was unable to answer have now been satisfactorily resolved - for example, the pathways which carry impulses from the auditory and visual sensory cortical centers to the prefrontal lobe (see p. 4 of the present paper), the connexions between the individual fields within the "association zones" and those between the frontal and temporo-parieto-visual "association" zones: as we have seen, most are now well established by recent research using modern degeneration techniques, the electron-microscope and electroanatomical or electrophysiological methods. He might also feel pride in his early work, in 1905, on the motor and somatosensory cortices in the human brain, and in his prescient ideas about what Mountcastle and his colleagues later named "command function of movements" directed by centers within the parietal lobe.

Flechsig regarded the posterior association zone as the seat of intelligence - a term which corresponded to nineteenth century ideas of localization and which, as Schröder (1930) said, was "outmoded" in the early decades of this century. As described on p. 96, however, Flechsig's term has been gradually transformed by neuropsychologists and physiologists into acceptable terms of the function of this zone in which motor and sensory impulses are transformed into highly complex patterns important for action, thinking, language and the consciousness of the self. Flechsig had considered consciousness of the self as the principal function of the prefrontal zone, but in this he was mistaken as Sperry and his associates have convincingly demonstrated. Whatever one's philosophical attitude to the brain- mind problem may be, the gap between the working of the "mind" and our knowledge about the "integrated action" of the brain has been substantially narrowed by the progress made in the last three decades.

Yakovlev's imposing collection of 800 brains, cut in serial and mounted sections, has now been transferred as the "Yakovlev Bequest" to the Armed Forces' Institute of Pathology in Washington, D.C. Significant probes - still supported by the critical advice of Yakovlev - have been made by a Hanoverian research group (Kretschmann, Schleicher, Grottschreiber and Kullmann, 1979): these investigators have confirmed its great value for future morphogenetic research. Implicitly such further progress would also help to sustain the memory of the early pioneering work by Paul Flechsig.

\section{ACKNOWLEDGEMENTS}

I greatly appreciate the honor of having been invited by Dr. R.T. Ross to submit a paper for publication in this Journal. I also wish to thank Charles C. Thomas. Publisher. Springfield, Illinois, for permission to include some lengthy quotations from pages $183-185$ of von Bonin. G. "Some Papers on the Cerebral Cortex", Ist edition. 1960. There is no copyright problem about the illustrations since Flechsig died more than 50 years ago.

It is a pleasure to record my grateful thanks to Dr. Raymond Hierons for his encouragement and his comments on the manuscript and to Dr. Nina Meyer for improving its style.

\section{REFERENCES}

ARIENS KAPPERS, C.U. (1909). The phylogenesis of the palacocortex and archicortex compared with the evolution of the visual neocortex. Arch. Neurol. Psychiat. (Lond.) 4 , $161-173$.

BAILEY, P. and BONIN, G. von (195I). The Isocortex of Man. Urbana, Ill.: Univ. of Jilinois Press.

BECHTEREW, W. (1885). Über die Schleifenschicht. Neurol, Zbl. 4, 356-359.

BIANCHI, L. (1895). The functions of the frontal lobes. Brain. $18,497-522$.

BIANCHI. L. (1922). The Mechanisms of the Brain and the Function of the Frontal Lobes (transl. by J.H. MacDonald). Edinburgh and New York: 1.ivingstone.

BONIN, G. von (1942). The striate area of primates. J. Comp. Neurol. 77, 405-429.

BONIN. G. von (1944). Architecture of the precentral motor cortex and some adjacent areas. 1n: The Precentral Cortex (Ed. P.C. Bucy), pp. 7-82. Urbana: University of Illinois Press (2nd edition 1946).

BONIN. G. Y(on (1960). Some Papers on the Cerebral Contex. Springfield. III.: Thomas.

BONIN, G. von and MEHLER, W.R. (1971). On columnar arrangement of nerve cells in cerebral cortex. Brain Res. 27. 1-9.

BRICKNER. R.M. (1936). The Intellectual Functions of the Frontal Lobes. New York: Macmillan.

BRODMANN. K. (1909). Vergleichende Lokalisation der Grosshirnrinde. Chapter 9. Leipzig: Barth. (Iransl. by von Bonin. G.. 1960). In: Some Papers on the Cerebral Contex. pp. 201-230. Springfield. III.: Thomas.

BURDACH, K.F. (1819-1826). Vom Baue und Leben des Gehirns, 3 vols. l.eiprig: Dyk"sche Buchhandlung.
CHARCOT, J.-M. (1876). L.eçons sur les localisations dans les maladies du cerveau. pp. 232ff. Paris: Delahaye.

CLARKE. E.G. and OMALLEY. C.D. (1968). The Human Brain and Spinal Cord. Berkeley and Los Angeles: University of California Press.

COBB. S. (1943). Borderlands of Psychiatry. Cambridge. Mass. Harvard University Press.

COLONNIER, M.L. (1966). Structural design of the neocortex. In: Brain and Conscious Experience (Ed. J.C. Eccles) pp. I23. Berlin. Heidelberg. New York: Springer.

CRITCHI.EY, M. (1953). The Parietal Lobes. London: Arnold.

CRITCHLEY. M. (1978). Review on Brain mechanisms for directed attention (by Mountcastle, V.B.) J. Royal Soc. Medicine 71.233.

CUSHING. H. (1908). Surgery of the head. In: Surgery, its Principles and Practice (Ed. W.W. Keen) vol, 3. 17-276. Philadelphia: Saunders.

CUSHING. H. (1909). A Note Upon the Faradic Stimulation of the Post-Central Gyrus in Conscious Patients. Brain 32. $44-53$.

DEJERINE. J., avec la collaboration de Madame DejerineKlumpke (1901). Anatomie des Centres Nerveux. Tôme deuxic̀me. Paris: J. Rueff.

DENNY-BROWN, D. (1951). The frontal lobes and their functions. In: Modern Trends in Neurology (Ed. A. Feiling). pp. 13-89. L.ondon: Butterworths.

DENNY-BROWN. D. and CHAMBERS. R.A. (1958). The parietal lobe and behavior. Res. Publ. Ass. Res. Nerv. Ment. Dis.. 36, 35-117.

ECCLES. J.C. (1977). Part If in: The Self and its Brain (Eds. Karl R. Popper and John C. Eccles). Berlin, Heidelberg. London. New York: Springer.

ECONOMO, C. yon and KOSKINAS, GN, (1925). Die Cytoarchitektonik der Hirnrinde des erwachsenen Menschen. Wien and Berlin: Springer.

ETTLINGER. G. (1959). Visual discrimination following successive temporal ablations in monkeys. Brain. 82, 232250.

ETILINGER. G.. IWAI. E., MISHKIN. M. and ROSVOLD. H.E. ( 1968$)$. Visual discrimination in the monkey following erial ablation of inferotemporal and preoccipital cortex. J. Comp. Physiol. Psychol. 65, 110-117.

ETTL.INGER. G. and KALSBECK, J.E. (1962). Change in tactile discrimination and in visual reaching after successive and simultancous hilateral posterior parietal ablations in the monkev. J. Neurol. Neurosurg. Psychiatr. 25. 256-268.

FILIMONOFF. I.N. (1929). Zur embryonaten und postembryonalen Entwicklung der Grosshirnrinde des Menschen. J. Psychol. Neurol., 39, 323-389.

FILIMONOFF. I.N, (1947). A rational subdivision of the cerebral cortex. Arch. Neurol. Psychiatr, (Chic.) 58, 296311.

FLECHSIG, P. (1876). Die Leitungsbahnen im Gehirn und Rückenmark des Menschen. L.eipzig: Engelmann.

FLECHSIG. P. (1877). Ober Systemerkrankungen im Rückenmark. Arch. Heilk. 18, 10 1-483.

FI.ECHSIG, P. (188I). Zur Anatomie und Entwicklungsgeschichte der Leitungsbahnen im Grosshirn des Menschen. Arch. Anat. Physiologie (Anat. Abt.) 12-75.

FL.ECHSIG, P. (188.3). Plan des menschlichen Gehirns. Leipzig: Veit \& Co.

FLECHSIG, P. (1886). Zur Lethre vom centralen Verlauf der Sinnesnerven. Neurol, Zbl. 5. 545-551.

FLECHSIG, P. (1894). Ober ein neues Eintheilungsprinzip der Grosshirn-Oberfläche. Neurol. Zbl. 13, 674-676.

FLECHSIG, P. (1896). Gehirn und Seete. Leiprig: Veil \& Co.

FLECHSIG. P. (1898). Neue Untersuchungen über die Markbildung in den menschlichen Grosshirnlappen. Neurol, Zbl. 17, 979-996.

FLECHSIG. P. (1900). Les centres de projection el d'association du cerveau humain. XIlle Congr. Internat. de Méd.. Sect. de Neurol.. pp. II5-12I (quoted from Clarke \& O'Malley, 1968).

Fl.ECHSIG, P. (1901). Developmental (myelogenetic) locatisa. lion of the cerebral cortex in the human subject. Lancet 2 1027-1029.

FLECHSIG, P. (1904) Einige Bemerkungen über die Untersuchungsmethoden der Grosshirnrinde. insebesondere des Menschen, Ber. Verh. K. sächs. Gies. Wiss, l_eiprig. Math.-Phys. Kl. 56, 50-104; 177-248 (quoted from Clarke and OMalley. 1968).

FLECHSIG, $Y$. (1905a). Gehirnphysiologic und Willenstheorien. Sth Inti....t. Psychol. Congr. Rome, 73-89. (transl. by von Bonin, G.. 1960, in: Some Papers on the Cerebral Cortex. pp. $|8|-200)$. Springfield. III.: Thomas. 
FLECHSIG, P. (1905b). Einige Bemerkungen über die Untersuchungsmethoden der Grosshirnrinde, insbesondere des Menschen. Arch. f. Anat. Physiol. Anat. Abt. 337-444.

FLECHSIG. P. (1908). Bemerkungen über die Hörsphacre des menschlichen Gehirns. Neurol. Zbl. 27, 2-7; 50-57.

FL.ECHSIG, P. (1920). Anatomie des menschlichen Gehirns und Rückenmarks auf myelogenetischer Grundlage. L.eipzig: Thieme.

FLECHSIG. P. (1927). Meine myelogenetische Hirnlehre mit biographischer Einleitung. Berlin: Springer.

FOERSTER, O. (1936). Motorische Felder und Bahnen. Sensible corticale Felder. In: Handbuch der Neurologie (Eds. O. Bumke and O. Foerster), vol. 6, 1-448. Berlin: Springer.

GLOBUS, A. and SCHEIBEL. A.B. (1967). Pattern and field in cortical structure: the rabbit. J. Comp. Neurol. I31. I55172.

GOIDSTEIN K (1927). Die Lokalisation in der Grosshirnrinde. In: Mandbuch der Normalen und Pathologischen Physiologie (Eds. A. Bethe. G. Bergmann, G. Embden and A. Ellinger). Vol. 10, 600-842. Berlin: Springer.

GORDON. H.W., BOGEN. J.E. and SPERRY, R.W. (197I). Absence of deconnexion syndrome in two patients with partial section of the neocommissures. Brain, 94, 327-336.

GREY-WALTER. W.. COOPER. R., ALDRIDGE. V.J.. McCALLUM, W.C. and WINTER. A.l. (1964). Contingent negative variation: an electric sign of sensorimotor association and expectancy in the human brain. Nature. 203, 380-384.

GRosS. C.G., BENDER, D.B. and ROCHA-MIRANDA. C.E. (1974). Inferotemporal cortex: a single unit analysis. In: The Neurosciences Third Study Program, (Eds. F.O. Schmitt and F.G. Worden) pp. 229-238; 451-482

GRONBAUM. A.S.F. and SHERRINGTON, C.S. (1902). Observations on the physiology of the cerebral cortex of some of the higher apes. (Preliminary Communication read to R. Society on November 21, 1901)

GRUNBAUM, A.S.F. and SHERRINGTON, C.S. (1903). Observations on the physiology of the cerebral cortex of the anthropoid apes. Proc. R. Soc. 72. 152-155.

GUDDEN, B. von (1872), Uber den sog, paralytischen Grössenwahnsinn. Korresp. BI. Schweizer Ärzte 2, 78-82.

HAYMAKER, W. (1970). Paul Flechsig (1847-1929) In: The Founders of Neurology (Eds. W. Haymaker and F. Schiller) 2nd Edition, pp. 23-27. Springfield, Ill.: Thomas.

HEAD, H. (1926). Aphasia and Kindred Disorders of Speech. Cambridge University Press.

HUHEL, D.H. and WIESEL, T.N. (1963). Shape and arrangement of columns in cat's striate cortex. J. Physiol. 165, 559-568.

HUBEL, D.H. and WIESEL, T.N. (1965). Receptive fields and functional architecture in two nonstriate visual areas (18 and 19) of the cat. J. Neurophysiol. 28, 229-289.

HUBEL., D.H. and WIESEL. T.N. (1968). Receptive fields and functional architect ure of monkey striate cortex. J. Physiol. 195, 215-243.

HUAEL, D.H, and WIESEL, T.N. (1969). Anatomical demonstration of columns in the monkey striate cortex. Nature 221. 747-750.

HUBET, D.H. and WIESEL. T.N. (1972). Laminar and columnar distribution of geniculo-cortical fibers in the macaque monkey. J. Comp. Neurol. 146, 421-450.

JONES, E.G. (1968). An electron microscope study of the terminations of afferent fibre systems within the somatic sensory cortex of the cat. J. Anat (Lond.) 103, 595-597.

JONES. E.G. and POWELL. T.P.S. (1969). Connexions of the somatic sensory cortex of the Rhesus monkey. I. Ipsilateral cortical connexions. Brain 92, 477-502.

JONES, E.G. and POWELL., T.P.S, (1970a). An anatomica study of converging sensory pathways within the cerebral cortex of the monkey. Brain 93, 793-820.

JONES, E.G. and POWELL, T.P.S. (1970b). Electron microscopy of the somatic sensory cortex of the cat. (In 5 parts) Philos. Trans. B. 257, 1-62.

JONES, E.G. and WISE. S.P. (1977). Size, laminar and columnar distribution of efferent cells in the sensory-motor cortex of monkeys. J. Comp. Neurol. 175, 391-437.

KAES, T. (1907). Die Grosshirnrinde des Menschen in ihren Massen und in ihrem Fasergehalt. Jena: Gustav Fischer.

KLOSE, R. (1920). Das Gehirn eines Wunderkindes (des Pianisten Goswin Sökeland). Mschr. Psychiat. Neurol. 48, 63-102.

KL.UVER. H. and BUCY, P.C. (1939). Preliminary analysis of the functions of the temporal lobes in monkeys. Arch. Neurol. Psychiat. (Chic.) 42, 979-1000.
KORNHUBER, H.H. (1974). Cerebral cortex, cerebellum and basal ganglia: an introduction to their motor functions. In: The Neurosciences Third Study Program (Eds. F,O. Schmitt and F.G. Worden) pp. 267-280. Cambridge (Mass.) and London: The MIT Press.

KRAUSE. F. (1911). Chirurgie des Gehirns und Rückenmarkes nach eigenen Erfahrungen. 2 vols. Berlin: Urban und Schwarzenberg.

KRETSCHMANN, H.J.. SCHLEICHER, A.. GROTTSCHREIBER, J.F. and KULLMANN, W. (1979). The Yakovlev Collection a pilot study of its suitability for the morphometric documentation of the human brain. J. Neurol. Sci. 43, 111-126.

KUYPERS. H.G.J.M.. SZWARCBART. M.K.. MISHKIN. $M$. and ROSVOLD, H.E. (1965). Occipitotemporal corticocortical connections in the Rhesus monkey. Exp. Neurol. II, 245-262.

LANGWORTHY. O. (1933). Development of behaviour patterns and myelination of the nervous system in the human fetus and infant. Contrib. Embryol. 139. 1-57.

LEVAY, S.. HUBEL. D.H. and WIESEL. T.N. (1975). The pattern of ocular dominance columns in macaque visual cortex revealed by a reduced silver stain. J. Comp. Neurol. 159, 559-576.

LIBET, B. (1966). Brain stimulation and the threshold of conscious experience. In: Brain and Conscious Experience (Ed. J.C. Eccles) pp. 165-181. Berlin. Heidelberg, New York: Springer.

LIBET, B. (1973). Electrica! stimulation of cortex in human subjects, and conscious aspects. In: Handbook of Sensory Physiology, vol. 2. (Ed. A. Iggo) pp. 743-790. Berlin, Heidelberg. New York: Springer (quoted from Eccles, 1977 , Heidelberg,
pp. 256-257.)

LOOS, H. van der and WOOLSEY, T.A. (1973). Somatosensory cortex: structural alterations following early injury to sense organs. Science 179.395-398.

LORENTE DE NÓ. R. (1949). Architectonics and structure of the cerebral cortex. In: Physiology of the Nervous System (Ed. J.F. Fulton) 3rd. ed., pp. 288-330. New York: Oxford University Press.

LUND, J.S. (1973). Organization of neurons in the visual cortex, area 17, of the monkey (Macaca mulatta). J. Comp. Neurol. 159. 305-334.

MARIN-PADILLA. M. (1970). Prenatal and early postnatal ontogenesis of the human motor cortex: A Golgi study. II. The basket-pyramidal system. Brain Res. 23, 185-191.

MARSHALL. W.H. and TALBOT. S.A. (1942). Recent evidence for neural mechanisms in vision leading to a general theory of sensory acuity. Biol. Sympos. 7, 117-164.

McFIE. J. (1961). Recent advances in phrenology. Lancet 2.360363.

MEYER, A. (1971). Historical Aspects of Cerebral Anatomy. London: Oxford University Press.

MEYER. A. (1974). The frontal lobe syndrome, the aphasias and related conditions a contribution to the history of cortical localization. Brain 97, 565-600.

MIL.LS、C.K. and FRAZIER、C.H. (1905-1906). The motor area of the human cerebrum. Its position and its subdivisions. with some discussions of the surgery of this area. Univ. Pennsylvania Med. Butl. 18, 135-147.

MISHKIN. M. (1954). Visual discrimination performance following partial ablations of the temporal lobe: II. Ventral surface vs hippocampus. J. Comp. Physiol. Psychol. 47. 187-193.

MISHKIN, M, and PRIBRAM. K.H. (1954). Visual discrimination performance following partial ablations of the temporal lobe: I. Ventral surface vs lateral. J. Comp. Physiol. Psychol. 47, 14-20.

MOLLIVER, M.E. and LOOS, H. van der (1969). The synaptic strata of the somesthetic cortex in neonatal dog. Anat. Record. 163, 317-318.

MONAKOW, C. von (19II). L.okalisation der Hirnfunktionen. J. Psychol. and Neurol. 17, 185-200. (transl. by Bonin, G. von, 1960, in: Some Papers on the Cerebral Cortex, pp. 231. 250).

MOUNTCASTLE, V.B. (1957). Modality and topographic properties of single neurons of cat's somatic sensory cortex. J. Neurophysiol. 20, 408-432.

MOUNTCASTLE, V.B. (1975). The Dean's Lecture: The view from within: pathways to the study of perception. The Johns Hopkins Med. J. 136, 109-131.

MOUNTCASTLE, V.B. (1978). Brain mechanisms for directed attention (Sherrington Memorial Lecture). J.R. Soc. Medicine $71,14-28$.

MOUNTCASTLE, V.B., LYNCH, J.C., GEORGOPOULOS, A. SACATA, H. and ACUNA, C. (1975). Posterior parietal association cortex of the monkey: command functions for operations within extrapersonal space. J. Neurophysiol, 38, 871-908.

MUNK. H. (1890). Ober die Funktionen der Grosshirnrinde. Gesammette Mittheilungen aus des Jahren 1877-1880. (second ed., first published 1881). Berlin: Hirschwisld.

NAUTA. W.J.H. (1971). The problem of the frontal lote: A reinterpretation. J. Psychiat. Research 8. 167-187.

PANDYA, D.N., HALLETT, M. and MUKHERJEE. S.K. (1969). Intra- and interhemispheric connections of the neocortical auditory system in the Rhesus monkey. Brain Res. 14, 49-65.

PANDYA, D.N. and KUYPERS. H.G.J.M. (1969). Corticocortical connections in the rhesus monkey. Brain Res. 13, 13-36.

PENFIELD. W. (1958). Centrencephalic integrating system. Brain 81, 231-242.

PFEIFER. R.A. (1921). Die Lokalisution der Tonskala innerhalb der kortikaten Hörsphäre des Menschen. Mschr. Psychiat. Neurol. 50. 7-48; 99-108.

PFEIFER, R.A. (1930). Necrolog. Paul Flechsig. Sein Lehen und Wirken. Schweiz. Arch. Neurol. Psychiat. 26, 258-264.

PFEIFER, R.A. (1936). Pathologie der Hörstrahlung und der corticalen Hörsphäre. In: Handbuch der Neurologic. (Eds. $O$. Bumke and $O$. Forster) Berlin: Springer, vol. 6. 533-626.

PHILLIPS, C.G, and PORTER, R. (1977). Corticospinal Neurones. Their Role in Movement. L.ondon, New York, San Francisco: Acad. press.

PHILLIPS. C.G.. POWEI.L. T.P.S. and WIESENDANGER, M. (197|). Projection from low-threshold muscle afferents of hand and forearm to area $3 \mathrm{a}$ of baboon's cortex. J. Physiol. 217, 419-446.

PIERCY. M. (1964). The effects of cerebral lesions on intellectual function, $\mathrm{Br}$. J. Psychiat. 110, 310-352.

POWELL. T.P.S. and MOUNTCASTLE. V.B. (1959). The cytoarchitecture of the postcentral gyrus of the monkey macaca mulatta. Johns Hopkins Hosp. Bull. 105. 108-132.

PRIBRAM, K.H. (1970). Introduction to the discussion on neural subsystems. In: The Neurosciences Second Study Program (Ed. F.O. Schmitt) p. 187. New York: The Rockefeller University Press.

RAMON Y CAJAL. S. (1899). Estudios sobra tis cortema cerebral humana. Rev. Trimestral Micrographia 4. 1-63 (transl. into German by J. Bresler, 1900, as: Studien über die Hirntinde des Menschen, Heft 1. pp. 1-77, Leciprig: Barth).

RAMÓN Y CAJAL. S. (1904), Textura del sistema nervioso del Hombre $y$ de los Vertebrados, Vol. 2. Madrid: Moya

RAMON Y CAJAL. S. (19|1). Histologie du Système Nerveux de L'homme et des Vertebrates. Vol. 2, chapter 36. (transl. by Bonin. G. von. 1960. in: Some Papers on the Cerebral Cortex, pp. 251-282)

ROSE. M. (1927). Gyrus limbicus anterior and retrosplenialis (cortex holoprotoplychus quinquestriatus). J. Psychol. Neurol. 35, 65-173.

RUSSELL.. W.R. (1948). Functions of the frontal lobes. Lancet l. $356-360$.

SCHEIBEL. M.E. and SCHEIBEL., A.B. (1958). Structural substrates for integrative patterns in the brain-stem reticular core. In: Reticular Formation of the Brain. (Eds. H.H. Jasper, L.D. Proctor, R.S. Knighton, W.C. Noshay, R.T. Ostello) Boston (Mass.): L.ittle, Brown \& Co.

SCHEIBEL, M.E. and SCHEIBEL. A.B. (1969). Termina! paterns in cat spinal cord. III: Primary afferent collaterals. Brain Res. 13. 417-443.

SCHEIBEL. M.E. and SCHEIBEL. A.B. (1970). Elementary processes in selected thala mic and cortical subsystems the siruciural substrates. In: The Neurosciences Second Study Program (Ed. F.O. Schmitt), pp. 443-457. New York; Rockefelter University Press.

SCHRÖDER, P. (1930). Paul Flechsig. Arch. Psychiat. Nervenkr. 91, 1-8.

SHOLL. D.A. (1955). The organization of the visual cortex in the cat. J. Anat. L.ond., 89, 33-46.

SHOLL. D.A. (1956). The Organization of the Cerebral Cortex. London: Methuen.

SPERRY. R.W. (1974). Lateral specialization in the surgically separated hemispheres. In: The Neurosciences Third Study Program (Eds. F.O. Schmitt and F.G. Worden) pp. S-19. Cambridge (Mass.) and London: The MIT Press.

SZENTÁGOTHAI, J. (1965a). The use of degeneration methods in the investigation of short neuronal connections. In: Degeneration Patlerns in the Nervous System (Eds. M. Singer and J.P. Schadé). pp. 14-32. Amsterdam: Elsevier. 
SZENTAGOTHAL, J. (1965b). The use of degeneration methods in the investigation of short neuronal connections. Progr. Brain Res. 14, 1-32.

SZENTKGGOTHAL. J. (1975). The 'module concept' in cerebral cortex architecture. Brain Res. 95. 475-496.

voGT. C. \& $O$. (19|9), Allgemeinere Ergebnisse unserer Hirnforschung. J. Psychol. Neurol. (Suppl.) 25. 279-462.

VOGT. M. (1928). Ober omnilaminäe Structurdifferencen und lineäre Grenzen der architektonischen Felder der hinteren Zentralwindung das Menschen. J. Psychol. Neurol. 35, 177 193.

SZENTÁGOTHAL, J. and ARBIB. M.A. (1975). Conceptual Models of Neural Organization. Cambridge (Mass.) and London: The MIT Press.

TOMBOL. T. (1972). A Golgi Analysis of the Sensory-motor Cortex. In: Synchronization of E.E.G. Activity in Epileptics (Eds. H. Petsche and M.A.B. Brazier) pp. 25-36. Wien, New York: Springer.

vOGT. O. (1901). Zur Hirnfaserlehre. Allgem. Z. Psychiat. Neurol. 58, 707-709.
vOGT. O. (1903). Zur anatomischen Gliederung des cortex cerebri. J. Psychol. Neurol. 2. 160-180.

WEISKRANTZ, L. (1974). The interaction between occipital and temporal cortex in vision. In: The Neurosciences Third Study Program (Eds. F.O. Schmitt and F.G. Worden) pp. 189-204. Cambridge (Mass.) and London: The MIT Press.

WHITTACKER. V.P. and GRAY. E.G. (1962). The synapse: biology and morphology. Br. Med. Bull. 18. 223-228.

WIESEL. T.N.. HUBEL. D.H. and LAM. D. (1974). Autoradiographic demonstration of ocular dominance columns in the monkey striate cortex by means of transsynaptic transport. Brain Res. 79, 273-279.

WIESENDANGER, M. (1973). lnput from muscle and cutaneous nerves of the hand and forearm to neurones of the precentral gyrus of baboons and monkeys. J. Physiol. 228, precentral 219.

WOOLSEY, T.A, and L.OOS, H. van der (1970). The structural organization of layer IV in the somatosensory region (SI) of mouse cerebral cortex. The description of a cortical field composed of discrete units. Brain Res. 17. 205-242.
YAKOVLEV. P.I. (1962). Morphological criteria of growth and maturation of the nervous system in man. Res. Publ. Ass Nerv. Ment. Dis, vol, 39. 3-46.

YAKOVIEV, P.I. and LECOURS. A.R. (1967). The myelogenetic cycles of regional maturation of the brain. In: Regional Development of the Brain in Early Liec (Ed. A. Minkowski) pp. 3-70. Oxlord, Edinburgh: Blackuell Scientific Publications:

YOUNG. J.Z. (1964). A Model of the Brain. Oxford: Clarendon Press.

YOUNC, J.Z. (1978). Programs of the Brin. Osford: Universily Press.

YOUNG. J.Z. (1979). Learning as a process of selection and amplification: Hughlings Jackson Lecture. J.R. Soc. Med. 72. $801-814$. 